\title{
ОСОБЛИВОСТІ ІНФОРМАЦІЙНОГО ЗАБЕЗПЕЧЕННЯ ІНФОРМАЦІЙНО-КОМУНІКАТИВНОЇ ДІЯЛЬНОСТІ У ВИЩІЙ РАДІ ПРАВОСУДДЯ
}

\author{
АРТЕМЕНКО Олена Вікторівна - кандидат юридичних наук, доцент, доцент \\ кафедри адміністративного та фінансового права Національного університету \\ біоресурсів і природокористування України \\ https://orcid.org/0000-0003-2041-8925 \\ БОВСУНОВСЬКИЙ Микола Олесевич - здобувач другого (магістерського) \\ рівня вищої освіти Національного університету біоресурсів і природокористування \\ України
}

DOI 10.32782/LAW.UA.2021.3.8

В научной статье исследованъ и охарактеризировань особенности инбормационного обеспечения информационно-коммуникационной системь органов государственной власти в том иисле и независимого конституиионного органа государственной власти и судейского управления - Въисшего совета правосудия. Рассмотрено нормативное закрепление понятия Въгсший совет правосудия и его полномочия. Определено, что ряд полномочий, которъие осуществляет Висший совет правосудия, касается инбормационно-нормативного, инбормачионно-аналитического, инбормационноорганизачионного обеспечения деятельности судов. Исследовано нормативно-правовую основу инбормационно-коммуникационной деятельности органов правосудия и принициви, на которьх базируется инбормационное законодательство Украиньг в изелом. Проанализирован Информационно-аналитический отчет о деятельности Выссшего совета правосудия в 2020 году и определень основньие приоритетнъе направления деятельности в сфере информационно-коммуникативной политики. Также рассмотрен План деятельности Вьсшего совета правосудия на 2021 - 2023 годъ.

Кроме того, в прочессе исследования бъл обозначен ряд проблем, которьие негативно влияют на развитие и эфбективность информационно-коммуникативной деятельности Въгсшего совета правосудия и влияние этого фактора на доверие общества. Рассмотрено содержание информационно-коммуникатив- ной деятельности в органах государственной власти, и доказана необходимость перехода органов государственного управления на новъге приниипь взаимодействия с общественностью. Определен ряд мер, направленнълх на достижение более эбббективного правового регулирования в сбере информачионного обеспечения. Введение указанньх мероприятий даст возможность для совершенствования инбормачионно-коммуникативной деятельности Виясшего совета правосудия, будет способствовать утверждению и закреплению статуса Украинъ в международном сообществе как государства с налаженной системой инбормаиионно-коммуникативнъгх связей среди органов государственной власти и местного самоуправления, а также органов правосудия.

Ключевъе слова: инбормационное обеспечение, информационно-коммуникативная система, Высший совет правосудия, инбормаилонная среда, принципь инбормационного законодательства.

\section{Постановка проблеми}

Інформаційно-комунікаційна діяльність виступає важливим атрибутом діяльності органів державної влади в сучасних умовах, виконуючи цілу низку важливих функцій, серед яких - функція створення інформаційних каналів для обміну інформацією між окремими організаціями, працівниками та громадськістю. Еволюція вітчизняного законодавства, що регулює ін- 


\section{Адміністративне право}

формаційні відносини в органах державної влади, відбувається поетапно та залежить від багатьох факторів, основними з яких 6 розвиток інформаційних технологій, правові реформи та імплементація міжнародного законодавства [1, с.354]. На сьогодні, напевно, не залишилося такого органу, одним із пріоритетних напрямків діяльності якого 6 не було утвердження та подальше налагодження інформаційно-комунікативної системи (далі- IКС) адже саме цей вид діяльності, у свою чергу, є показником ефективної роботи, а також сприяє підвищенню рівня довіри громадськості. Проте, виклики сьогодення, спричинені пандемією COVID-19, чітко сформували розуміння неспроможності багатьох органів державної влади діяти у вищезазначених умовах послідовно та узгоджено, що, у свою чергу, негативно впливає на рівень довіри населення.

\section{Стан дослідження}

Питання інформаційного забезпечення інформаційно-комунікаційної діяльності органів державної влади в умовах, пов'язаних 3 викликами сучасності, 6 напрочуд актуальним. Серед науковців, які прямо чи опосередковано досліджували цю тематику, є наступні : Г. Блінова ,О. Кондратенко, М. Смолович, М. Швець, ^. Корчевна, П. Клімушин, А. Клименко, Д. Біленська, А. Чікановський, В. Бакуменко, Ю. Нестеряк, В. Раца, І. Короленко та ін. Слід зазначити, що особливостям інформаційного забезпечення інформаційно-комунікативної діяльності у Вищій раді правосуддя окремих досліджень присвячено не було, що вкотре підтверджує актуальність вибраної тематики.

Метою статті є дослідження особливостей інформаційного забезпечення інформаційно-комунікативної діяльності у Вищій раді правосуддя та формування пропозицій щодо удосконалення його функціонування.

\section{Виклад основних положень}

У сучасних умовах адаптації українського законодавства до європейського перед нашою державою ставляться високі стандарти та вимоги щодо всіх сфер суспільного життя. Право на справедливий суд вважається одним 3 фундаментальних принципів існування у системі глобальних цінностей демократичного суспільства.У свою чергу, реалізація права на справедливий, чесний та неупереджений судовий захист інтересів як фізичних, так і юридичних осіб судами, суттєво підвищує рівень інвестиційної привабливості держави, що, безперечно, впливає на їі прогрес та процвітання.

Як зазначає М. Смокович, реформування судової системи, яке отримало новий поштовх із впровадженням новацій у сфеpi правосуддя 2016 р., кардинально змінило всі головні аспекти діяльності судів і суддів, починаючи від засад судоустрою держави, власне системи судів та їхніх повноважень, механізму добору суддів до підстав і порядку їхньої відповідальності, системи забезпечення діяльності судів і засад суддівського самоврядування [2, с.15].

Першим у вітчизняній історії органом, що мав втілювати інституційну незалежність суддів, була Вища рада юстиції, яка діяла відповідно до ст.1 Закону України «Про Вищу раду юстиції» від 15 січня 1998 року (втратив чинність від 21.12.2016 р.). Варто зазначити, що створення Вищої ради юстиції в Україні сприймалось як позитивний крок на шляху до посилення незалежності суддів, хоча при цьому відзначались і певні недоліки ії нормативноправового регулювання.

Важливим етапом на шляху подальшого зміцнення незалежності судової влади в Україні можна вважати реформування 2016 р. та створення на базі Вищої ради юстиції Вищої ради правосуддя (далі - ВРП), яка відповідно до ст. 1 Закону України «Про Вищу раду правосуддя» визначена «...колегіальним, незалежним конституційним органом державної влади та суддівського врядування, який діє в Україні на постійній основі для забезпечення не- залежності судової влади, їі функціонування на засадах відповідальності, підзвітності перед суспільством, формування доброчесного та високопрофесійного кор- 
пусу суддів, додержання норм Конституції і законів України, а також професійної етики в діяльності суддів і прокурорів» [3].

У свою чергу, ст. 131 Конституції України містить перелік повноважень ВРП. Відповідно до цього ВРП 1) вносить подання про призначення судді на посаду; 2) ухвалює рішення стосовно порушення суддею чи прокурором вимог щодо несумісності; 3) розглядає скарги на рішення відповідного органу про притягнення до дисциплінарної відповідальності судді чи прокурора; 4) ухвалює рішення про звільнення судді з посади; 5) надає згоду на затримання судді чи утримання його під вартою; 6) ухвалюе рішення про тимчасове відсторонення судді від здійснення правосуддя; 7) вживає заходів щодо забезпечення незалежності суддів; 8) ухвалює рішення про переведення судді 3 одного суду до іншого; 9) здійснюе інші повноваження, визначені цією Конституцією та законами України [4].

Зміст наведених нормативно закріплених положень дає змогу стверджувати, поперше, про істотне збільшення обсягу та перерозподіл на користь Вищої ради правосуддя повноважень, які до реформи належали Верховній Раді України й Президенту України, а по-друге, про посилення ролі Вищої ради правосуддя у вирішенні питань не лише щодо формування суддівського корпусу, але й щодо адміністрування суддів, контролю за бюджетно-фінансовими питаннями їх забезпечення, впливу на суддівську кар'єру тощо.

Слід зауважити, що такий підхід викликав особливе схвалення вітчизняного та зарубіжного експертного середовища, оскільки в умовах «...визнання двох груп ключових завдань суддівських рад, перша 3 яких стосується суддівської кар'єри, друга - взаємодії судової влади 3 іншими гілками влади, небагато країн-членів Ради Европи визначають ці два завдання для судових рад і наділяють цей орган відповідними повноваженнями» [5, с. 52].

Окрім того, таке законодавче визначення конституційного органу державної влади, у якому міститься посилання на підзвітність перед суспільством, свідчить про необхідність досконалої реалізації інформаційно-комунікативної діяльності ВРП.

Реалізація наведених повноважень обумовлює в суді документообіг, який дає можливість говорити про здійснення ВРП:

- інформаційно-нормативного;

- інформаційно-аналітичного;

- інформаційно-організаційного забезпечення діяльності судів;

- а також інформаційного забезпечення захисту незалежності суддів.

Як зазначає В. Раца, повноваження ВРП, яка є суб'єктом судового ладу, корелюються 3 відповідними інформаційними сферами діяльності судів як суб'єктів судового устрою, що $є$ необхідною умовою та основою їх комунікації (взаємодії) як суб'єктів єдиної системи (судової системи), що, у свою чергу, є неодмінним елементом системоутворюючого процесу та забезпечує цілісність судової системи [6, с. 131].

Адже, як зазначають дослідники теорії систем, «сукупність певної кількості елементів стає системою лише тоді, коли між ними заданий якийсь закон взаємодії майбутні структурні закономірності системи» $[7$, с.205]. Отже, інформаційне забезпечення діяльності судів 6 не просто компонентом управлінської чи організаційної функції, а сферою, у якій відображаються та реалізуються системоутворюючі зв'язки судової системи.

Щодо нормативно-правового підгрунтя інформаційно-комунікаційної діяльності органів правосуддя, то варто зазначити, що воно закладено у Законі України “Про інформацію" - загальному нормативноправовому акті, який відображає головні положення міжнародних стандартів у сфері інформаційних відносин [8].

Ми вбачаємо за необхідно зазначити засади, на яких будується інформаційне законодавство в цілому, оскільки вони безпосередньо стосуються інформаційного забезпечення органів судової влади:1) загальні принципи Конституції України; 2) принципи свободи створення, отримання, використання та розповсюдження інформації; 3) об'єктивності, достовірності, повноти і точності інформації;4) гармонізації інтересів людини, суспіль- 


\section{Адміністративне право}

ства та держави в інформаційній діяльності; 5) обов'язковості публікації інформації, яка має важливе суспільне значення; 6) обмеження доступу до інформації виключно на підставі закону; 7) мінімізації негативного інформаційного впливу та негативних наслідків функціонування IКТ; 8) недопущення незаконного розповсюдження, використання і порушення цілісності інформації; 9) гармонізації інформаційного законодавства та всієї системи вітчизняного законодавства.

Принципи справжньої демократіi: - свобода слова та право доступу до інформації разом із верховенством права є основою побудови громадянського суспільства як в окремій державі, так і в цивілізованому світовому співтоваристві загалом. Із трьох найвідоміших серед наукової спільноти правових моделей діяльності засобів масової комунікації у суспільстві - американської, англійської та французької, на думку українського науковця В.Шкляра, Україна прагне саме до останньої [9, с. 231].

Таким чином, варто зазначити, що для формування у Вищій раді правосуддя ефективної стратегії реалізації механізмів інформаційно-комунікаційної діяльності необхідним буде дотримуватися наступних принципів: законності, відкритості, партнерства, єдності, стратегічного управління та зворотного зв'язку, як основних, а також ряду інших, що будуть використовуватися в залежності від цілей такої стратегії.

Аналізуючи Звіт діяльності Вищої ради правосуддя за 2020 рік, можна побачити, що особливе місце належить діяльності у сфері інформаційно-комунікативної політики, що, у свою чергу, означає необхідність постійного вдосконалення сучасної системи. Пріоритетними для ВРП залишаються динамічна робота із журналістами, забезпечення вчасної, адекватної, побудованої на зрозумілих фактах реакції на журналістські матеріали. ВРП протягом звітного року демонструвала політику доступності та відкритості у роботі з медіа, оперативно надаючи представникам 3МІ та громадськості повну інформацію про діяльність Ради [10].
Відповідно до Плану діяльності Вищої ради правосуддя на 2021-2023 роки з метою забезпечення прозорості у своїй діяльності ВРП продовжує політику інформаційної відкритості як перед органами державної влади, так і перед суспільством. Засідання Вищої ради правосуддя транслюються у режимі онлайн та є доступними для перегляду на їі офіційному веб-сайті [11]. Підтвердженням виконання вищезазначеного Плану є оприлюднення на офіційному веб-сайті ВРП рішень Ради та висвітлення всіх аспектів іiї діяльності (щодо робочих засідань, тендерів, фінансових звітів). Так, у 2020 році на офіційному веб-сайті розміщено понад 990 новин та повідомлень, близько 260 анонсів, 238 оперативних результатів розгляду питань порядку денного засідань, 3702 акти Вищої ради правосуддя. Окрім цього, у 2020 році ВРП було відредаговано 27618 документів.

Як зазначено в інформаційно-аналітичному звіті про діяльність Вищої ради правосуддя у 2020 році, кількість підписників офіційної сторінки ВРП за звітний період у Facebook зросла майже до 20 000, у Telegram - майже до 1 000, кількість переглядів матеріалів на YouTube- каналі ВРП на кінець року становить 46 600. Це може свідчити лише про неабиякий інтерес громадськості до цього органу та його діяльності.

Незважаючи на те, що рівень інформованості як на офіційних сторінках ВРП, так і сторінках інших державних органів 3 кожним роком зростає, ми переконані, що рівень правової свідомості населення нашої держави залишається на посередньому рівні. Одним із факторів вищезазначеної тези є низька інформованість саме сільського населення, чисельність яких, за даними Т. Осташко, станом на 2019 рік становить $31,1 \%$ від усього населення України [12]. У свою чергу, це впливає на дезінформованість унаслідок черпання інформації лише з окремих джерел, які для підвищення рейтингів часто нівелюють важливістю донесення об'єктивних фактів.

Вважаємо, що для вирішення цієї проблеми доцільно було б створити центри правового інформування населення при 
територіальних громадах, основним напрямком діяльності яких було б донесення правової інформації в усній формі до жителів територіальних громад у рамках проведення семінарів та обговорень. Оскільки, як зазначає сама ВРП, «одним із шляхів відновлення довіри є робота з інформування населення про підстави прийняття рішень, 3 роз'яснення процедур, згідно 3 якими діє Рада, принципів, які захищає ВРП, детальне, покрокове пояснення мотивів і причин дій, усіх процесів, які відбуваються у Раді» [11].

Також вважаємо за необхідне звернути увагу на необхідність сьогодні вдосконалювати механізми регулювання процесів обміну інформацією у Вищій раді правосуддя, зокрема результатом комунікативної реформи повинно стати всебічне вивчення громадської думки й своєчасне прогнозування критичної маси громадського невдоволення. Насамперед, варто зосередитись на першочергових заходах, а саме:

- визначенні пріоритетів у сфері суспільних комунікацій;

- забезпеченні взаємодії, побудови вертикальної і горизонтальної ієрархії комунікацій;

- узгодженні механізмів інформування та зворотного зв'язку;

- визначенні органу, відповідального за розроблення, впровадження та контроль за реалізацією державної комунікативної політики.

Оскільки у вітчизняному законодавстві чітко не визначені організаційно-правові засади діяльності інформаційних підрозділів, зокрема, не встановлено їх завдання та функції, відсутні уніфіковані підходи до формування їх структури та визначення місця в апараті органу влади. У зв'язку з цим необхідною умовою інституційного вдосконалення інформаційно-комунікативної діяльності державних органів може стати впровадження єдиних підходів до організаційної структури комунікативних підрозділів в органах державної влади, визначення їх цільових завдань та функцій. Підтвердженням цього факту є створення прес-офісу у структурі секретаріату Ви- щої ради правосуддя лише 28 травня 2020 року, після 4 років існування органу як такого.

На думку Д. Біленської, негативним фактором відзивається ще й те, що законотворець України значний масив нормативно-правових актів, які безпосередньо чи опосередковано впорядковують суспільні інформаційні відносини, розмістивши у законодавстві різних галузей права - у цивільному, адміністративному, трудовому або кримінальному. Доволі велика кількість законів та підзаконних нормативно-правових актів у сфері інформації ускладнюе їх пошуки, узгодження у практичному застосуванні, заважає здійсненню їх аналізу науковцями [13, с. 62].

Ще одним фактором, що затримує розвиток інформаційно-комунікативної системи органів державної влади, у тому числі і ВРП, є те, що інноваційний розвиток національних електронних комунікацій стримується низкою факторів, таких як низький рівень державного фінансування; відсутність науково-методологічної бази формування інформаційно-комунікативної системи; низька активність вітчизняних, закордонних інвесторів; відсутність координації дій суб'єктів інноваційної діяльності [14, с. 46].

Глибоке усвідомлення взаємозалежності проблем інноваційного суспільного розвитку і доступності до користування населенням інформацією власних інституцій сучасними IKT, інформаційна свобода та інноваційне мислення людини стають чинним стимулом для влади при формуванні всіх концепцій і програм розвитку країни, що підвищуе їі відповідальність при впроваджуванні більш досконалих норм поведінки.

\section{Висновок}

Для підвищення ефективності інформаційного забезпечення інформаційнокомунікативної діяльності ВРП необхідно створити в державі цілісну систему законодавства, гармонізовану 3 нормами міжнародного права 3 питань розвитку інформаційного суспільства. Удосконалення інформаційно-комунікативної діяльнос- 


\section{Адміністративне право}

ті Вищої ради правосуддя, сприятиме підвищенню рівня довіри населення до ВРП як органу суддівського врядування окремо, так і до органів правосуддя в цілому. Отже, у сучасних умовах інформаційно-комунікаційна діяльність повинна сприяти розкриттю потенціалу громадських структур, забезпечення більш активної участі громадян у діяльності органів державного управління (шляхом утворення центрів правового інформування на базі територіальних громад), а також підвищення відповідальності та підзвітності влади, побудові сучасної демократичної системи державного управління.

\section{література}

1. Блінова Г.О. Адміністративно-правові засади інформаційного забезпечення органів публічної адміністрації в Україні : актуальні питання теорії та практики : дис. ... д-ра юрид. наук : 12.00.07. Запоріжжя : ЗНУ, 2019. 545 с.

2. Смокович М. Незалежність судді як складова принципу верховенства права. Слово Національноӥ школи суддів України. 2018. № 2(23). С. 14-25.

3. Про Вищу раду правосуддя: Закон України від 21.12.2016 №1798-VIII. URL: http://zakon2.rada.gov.ua/laws/show/1798-19 (дата звернення 01.10.2021).

4. Конституція України : Закон України від 28.06. 1996 р. № 254к/96-BP. URL: https://zakon.rada.gov.ua/laws/show/254K/96вр\#Text (дата звернення 05.10.2021).

5. Корчевна $\mathcal{\Lambda}$. О. Створення Вищої ради правосуддя України в контексті посилення незалежності судової влади . Biсник Одесъкого національного університету. Серія : Правознавство. 2019. Т. 24, Вип. 2. C. 49-57. URL: http://nbuv.gov.ua/UJRN/ Vonu prav 2019 24_2 7n (дата звернення 08.10.2021).

6. Раца В. А. Організаційно-правові засади інформаційного забезпечення ро- боти суду : автореф. дис. ... канд. юрид. наук : 12.00.10; Нац. юрид. ун-т ім. Ярослава Мудрого. Харків, 2017. 20 с.

7. Прангишвили И. В. Системный подход и общесистемные закономерности. Серия «Системы и проблемы управления». М.: СИНТЕГ, 2000. 528 с.

8. Про інформацію: Закон України від 02.10.1992 р. No 2657-XII. URL: http:// zakon2.rada.gov.ua/laws/show/2657-12 (дата звернення 05.05.2017).

9. Шкляр В. І. Вектори часу. Україна на шляху до Европи : наук. вид. К. : Етнос, 2006. С. 226-264.

10. Інформаційно-аналітичний звіт про діяльність Вищої ради правосуддя у 2020 році. Вища рада правосуддя. 2020. URL: https://hcj.gov.ua/sites/default/files/field/file/ analiz za 2020 rik.pdf (дата звернення 10.10.2021).

11. План діяльності Вищої ради правосуддя на 2021-2023 роки. Вища рада правосуддя. 2020. URL: https:/hcj.gov.ua/sites/ default/files/field/file/plan diyalnosti vyshchoyi rady_pravosuddya na 2021-2023 roky.pdf (дата звернення 05.10.2021).

12. Осташко Т. Сільське населення України за 10 років скоротилося на 16 \%. URL: https://www.ukrinform.ua/rubricsociety/2736219-silske-naselenna-ukrainiza-10-rokiv-skorotilosa-na-16-ekspert.html (дата звернення 08.10.2021).

13. Біленська Д. О. Шляхи вдосконалення правового регулювання інформаційних правовідносин в Україні. Форум права. 2013. № 1. С. 60-64. URL: http://nbuv. gov.ua/UJRN/FP index.htm_2013_1_12d (дата звернення 05.10.2021).

14. Клімушин П. С. Електронна комунікація як механізм розвитку інноваційно орієнтованого суспільства. Теорія та практика державного управління. 2013. Вип. 3. С. 43-50. URL : http://nbuv.gov.ua/ UJRN/Tpdu 2013 $39 \mathrm{f}$ (дата звернення $08.10 .2021)$. 


\section{АНОТАЦІЯ}

У науковій статті досліджено та охарактеризовано особливості інбормаиійного забезпеченння інформачійно-комунікативної системи органів державної влади в тому числі i незалежного конституиійного органу державної влади та суддівсъкого врядування - Вищой ради правосуддя. Розглянуто нормативне закріплення поняття Вища рада правосуддя та ї повноваження. Визначено, що ряд повноважень, які здійснюе Вища рада правосуддя стосунться інбормачійно-нормативного, інбормачійно-аналітичного, інформачійноорганізачійного забезпечення діяльності судів. Досліджено нормативно-правове підгрунтя інформаиійно-комунікачійної діяльності органів правосуддя та засади на яких базується інформаиійне законодавство Украӥни в изілому. Проаналізовано Інформачійно-аналітичний звіт про діяльність Вищої ради правосуддя у 2020 рочі та визначено основні пріоритетні напрямки діяльності у сбері інбормаційнокомунікативної політики. Розглянуто План діяльності Вищої ради правосуддя на 2021 2023 роки.

Окрім того, в прочесі дослідження, було окреслено низку проблем, які негативно впливають на розвиток $і$ ефективність інформативно-комунікативної діяльності Вищої ради правосуддя та вплив иъого бактору на довіру суспільства. Розглянуто зміст інбормаиійнокомунікативної діяльності в органах державної влади та доведено необхідність переходу органів державного управління на нові приниипи взаємодї з громадськістю. Визначено низку заходів, направлених на досягнення більш ефбективного правового регулювання у сфері інформачійного забезпечення. Запровадження вказаних заходів дасть можливість для удосконалення інформаційно-комунікативної діяльності Вищої ради правосуддя, сприятиме утвердженню та закріпленню статусу України в міжнародній спільноті, як держави $i_{3}$ налагодженою системою інформаиійно-комунікативних зв'язків серед органів державной влади та місиевого самоврядування, а також органів правосуддя.

Ключові слова: інформаційне забезпечення, інформачійно- комунікативна система, Вища рада правосуддя, інбормащійне середовище, приничипи інформачзийного законодавства.

\section{SUMMARY}

The scientific article examines and characterizes the features of information support of the information and communication system of public authorities, including the independent constitutional body of state power and judicial governance - the High Council of Justice. The normative consolidation of the concept of the High Council of Justice and its powers are considered. It is determined that a number of powers exercised by the High Council of Justice relate to information and regulatory, information and analytical, information and organizational support of the courts. The normative-legal basis of information-communication activity of justice bodies and the principles on which the information legislation of Ukraine as a whole is based are investigated. The Information and Analytical Report on the Activities of the High Council of Justice in 2020 has been analyzed and the main priority areas of activity in the field of information and communication policy have been identified. The Plan of Activities of the High Council of Justice for 2021 - 2023 is considered.

The content of information and communication activities in public authorities is considered and the necessity of transition of public administration bodies to new principles of interaction with the public is proved. A number of measures aimed at achieving more effective legal regulation in the field of information support have been identified.The introduction of these measures will provide an opportunity to improve the information and communication activities of the High Council of Justice, will promote the establishment and consolidation of Ukraine's status in the international community as a state with an established system of information and communication between public authorities and local governments.

Keywords: information support, information and communication system, High Council of Justice, information environment, principles of information legislation. 